\title{
Pengaruh Jenis Pupuk Kandang Terhadap Pertumbuhan Dan Produksi Tanaman Sawi Hijau (Brassica juncea L.)
}

\author{
Melinda A. Jarangga*, Akhmad Ali*, Ajang Maruapey* \\ * Fakultas Pertanian UM Sorong
}

\begin{abstract}
Abstrak
Penelitian ini bertujuan untuk mengetahui pengaruh pemberian jenis pupuk kandang terhadap pertumbuhan dan hasil tanaman sawi hijau. Penelitian dilaksanakan di lahan petani KM 16 Kelurahan Klablim Distrik Sorong Timur Kota Sorong yang berlangsung pada bulan Sepetmber sampai dengan bulan November 2017. Penelitian ini dilakukan dengan menggunakan Rancangan Acak Kelompok (RAK) dengan 4 kali perlakuan dan 3 kali dengan, sehingga diperoleh 12 petak percobaan. Faktor perlakuan adalah sebagai berikut : $\mathrm{K}_{0}=$ Kontro. $\mathrm{K}_{1}=$ Pupuk kandang ayam $(1 \mathrm{~kg} /$ petak $) . \mathrm{K}_{2}=$ Pupuk kandang sapi $\left(1 \mathrm{~kg} /\right.$ petak). $\mathrm{K}_{3}=$ Pupuk kandang biogas $(1 \mathrm{~kg} /$ petak). Berdasarkan hasil yang diperoleh, maka dapat disimpulkan sebagai berikut: Pemberian berbagai jenis bokashi berpengaruh sangat nyata terhadap semua komponen yang diamati pada tanaman sawi hijau. Jenis bokashi pupuk kandang ayam memberikan pengaruh terbaik pada tinggi tanaman, jumlah daun, bobot segar per tanaman, bobot segar per petak dan bobot segar per ha tanaman sawi.
\end{abstract}

Kata Kunci : pupuk kandang, pertumbuhan, produksi, tanaman sawi

\section{PENDAHULUAN}

Perkembangan tanaman hortikultura, disamping untuk mewujudkan swasembada pangan, juga diharapkan untuk meningkatkan pendapatan masyarakat dan memperbaiki keadaan gizi melalui penganekaragaman jenis bahan makanan. Oleh karena itu, mencukupi kebutuhan pangan penduduk merupakan dasar utama untuk mewujudkan keberhasilan pembangunan di bidang Pertanian. Tanaman sayur dan buah merupakan tanaman hortikultura yang penting bagi manusia. Sayur dan buah dimanfaatkan sebagai pelengkap makanan pokok serta sebagai sumber mineral dan vitamin. Saat ini usaha budidaya tanaman sayur dan buah semakin banyak dilakukan petani maupun masyarakat sebagai mata pencaharian pokok atau sekedar hobi. Penanaman sayur dan buah semakin intensif dan meluas, terutama setelah diketahui bahwa hasil tanaman tersebut dapat diekspor dan memberikan keuntungan ekonomi yang tinggi (Suyanto, 2004). Tanaman sawi hijau merupakan salah satu jenis sayuran daun yang sudah dikenal baik oleh masyarakat Indonesia. Sayuran ini merupakan salah satu komoditi hortikultura yang memiliki nilai ekonomi dan prospek yang cukup baik untuk dikembangkan dan dapat diarahkan untuk meningkatkan pendapatan petani dan perluasan kesempatan kerja. Sawi hijau merupakan jenis sayuran yang populer. Sayuran yang dikenal pula sebagai caisim, caisin, atau sawi bakso ini mudah dibudidayakan dan dapat dimakan segar (biasanya dilayukan dengan air panas) atau diolah menjadi asinan (kurang umum). Sawi hijau ini memiliki banyak kegunaan di antaranya dapat dibuat sayuran tumis, lalapan ataupun asinan. Selain mempunyai rasa 
yang enak dan segar, sawi juga berguna untuk kesehatan tubuh manusia karena mengandung beragam zat makanan yang esensial bagi tubuh. Sawi hijau yang dikonsumsi dapat berfungsi sebagai penyembuh rasa sakit kepala, memperbaiki fungsi kerja ginjal serta pupuk organik. Akibat yang dapat ditimbulkan dari penggunaan pupuk kimia yang intensif antara lain menurunkan kesuburan fisik, kimia, dan biologi tanah, meningkatnya perkembangan patogen, keracunan unsur hara pada tanaman akibat terakumulasi disekitar akar serta menurunnya ketahanan tanaman terhadap serangan hama dan penyakit (Nurshanti, 2009). Pemanfaatan kotoran ternak sebagai pupuk organik adalah alternatif untuk meningkatkan produksi tanaman sawi hijau sehingga mampu meminimalkan pengaruh negatif tersebut. Namun pada kenyataannya kecepatan dekomposisi bahan organik dalam tanah tidak seiring dengan kecepatan pertumbuhan tanaman sawi yang relatif cepat, sehingga produksi sawi dari pertanian organik jauh lebih rendah daripada pertanian anorganik. Oleh karena itu perlu diterapkan suatu teknologi pertanian sebagai alternatif yang dapat meningkatkan kecepatan dekomposisi bahan organik sehingga bahan organik tersebut cepat mengalami pelapukan dan dapat diserap oleh tanaman (Sanusi, dkk. 2015). Pupuk organik ini dapat berasal dari pupuk kandang ataupun dari limbah industri. Suleman dkk, (2013) menjelaskan bahwa pupuk kandang memiliki sifat yang alami dan tidak merusak tanah, menyediakan unsur hara makro dan mikro, selain itu pupuk kandang berfungsi untuk meningkatkan daya menahan air, aktivitas mikrobiologi tanah, nilai kapasitas tukar kation dan memperbaiki struktur tanah. Pupuk organik yang dapat digunakan pada dapat memperlancar saluran pencernaan (Edi, dkk, 2010). Budidaya tanam sawi hijau yang intensif saat ini cenderung menggunakan pupuk kimia dalam jumlah yang besar untuk meningkatkan produksi tanpa diimbangi dengan penggunaan

tanaman sawi hijau yaitu pupuk kandang yang berasal dari kotoran sapi, kotoran kuda, kotoran kambing, kotoran ayam, kompos, kascing dan lain-lain. Penggunaan pupuk organik bermanfaat karena mengandung semua unsur yang diperlukan tanah, selain itu dapat berperan sebagai perekat partikel tanah sehingga agregasi dan struktur tanah menjadi baik.Aplikasi pupuk organik dalam sistem pertanaman dapat meningkatkan kandungan bahan organic atau organik dan kandungan $\mathrm{N}$ total dalam tanah (Zulkarnain dkk., 2013. Menurut Yuliana dkk (2017) Pupuk kandang memiliki sifat yang alami dan tidak merusak tanah, menyediakan unsur makro (nitrogen, fosfor, kalium, kalsium, dan belerang) dan mikro (besi, seng, boron, kobalt, dan molibdenium). Penelitian tanaman sawi hijau dengan menggunakan pupuk kandang yang dilakukan oleh Sulistiowati dan Susanti (2017) dengan dosis 20 ton/ha mampu meningkatkan jumlah daun, berat segar daun, berat berangkasan daun. selanjutnya penelitian mengkombinasikan pupuk kandang ayam dan sapi menunjukkan bahwa Perlakuan pupuk kandang ayam dengan dosis $2.5 \mathrm{~kg}$ per polibag memberikan rerata tertinggi terhadap jumlah daun tanaman dan luas daun tanaman sawi hijau. Dapat memberikan pengaruh terhadap diameter krop dan juga terhadap bobot brangkasan (basah dan kering). Berdasarkan uraian latar belakang di atas maka perlu dilakukan penelitian dengan judul" Pengaruh jenis pupuk kandang terhadap pertumbuhan dan hasil tanaman sawi hijau ". 


\section{Tujuan Penelitian}

1. Untuk mengetahui pengaruh pemberian jenis pupuk kandang terhadap pertumbuhan dan hasil tanaman sawi hijau

2. Untuk mengetahui pengaruh salah satu jenis pupuk kandang yang diberikan terhadap pertumbuhan dan hasili tanaman sawi hijau.

\section{METODOLOGI PENELITIAN}

\section{Tempat dan Waktu Penelitian}

Penelitian dilaksanakan di lahan petani KM 16 Kelurahan Klablim Distrik Sorong Timur Kota Sorong yang berlangsung pada bulan September sampai dengan bulan November 2017.

\section{Alat dan Bahan}

1. Alat yang digunakan dalam penelitian ini meliputi cangkul, Hand sprayer, Cangkul, parang, meteran, timbangan biasa, bambu, papan perlakuan Kamera, kalkulator, dan alat tulis menulis.

2. Bahan yang digunakan dalam penelitian ini adalah benih sawi hijau, pupuk kandang ayam, sapi dan biogas.

\section{Metode Penelitian}

Penelitian ini dilakukan dengan menggunakan Rancangan Acak Kelompok (RAK) dengan 4 kali perlakuan dengan 3 kali Ulangan sehingga diperoleh 12 petak percobaan. Faktor perlakuan adalah sebagai berikut:

$\mathrm{K}_{0}=$ Kontrol

$\mathrm{K}_{1}=$ Pupuk kandang ayam $(1 \mathrm{~kg} /$ petak $)$

$\mathrm{K}_{2}=$ Pupuk kandang sapi ( $1 \mathrm{~kg} /$ petak $)$

$\mathrm{K}_{3}=$ Pupuk kandang biogas (1 kg/petak)

\section{Pelaksanaan Penelitian}

1. Pembenihan

Benih merupakan salah satu faktor penentu keberhasilan usaha tani.
Benih yang baik akan menghasilkan tanaman yang tumbuh dengan bagus. Pembibitan dapat dilakukan pada bedengan kecil ukuran 1,20 x 1,20 meter ${ }^{2}$. Bedengan diolah sampai gembur kemudian ditaburi benih lalu ditutup dengan tanah olahan secukupnya dan disiram sampai permukaan bedeng basah. Setelah umur 2 minggu benih akan tumbuh selanjutnya dipindahkan ke bedengan yang telah disipakan.

2. Persiapan dan pengolahan tanah

Pertama-tama lahan yang disiapkan dibersihkan dari semaksemak dan sisa-sisa tanaman, kemudian tanah digemburkan dengan menggunakan cangkul. Tujuan dari pengolahan tanah adalah menggemburkan tanah, menghilangkan tanaman pengganggu, serta mengatur tata air dengan baik. Selanjutnya dibuat bedengan atau petak percobaan dengan ukuran 1,20 m x 1,20 meter. Di antara bedengan atau petak percobaan dibuat parit dengan ukuran $40 \mathrm{~cm}$ tinggi parit $30 \mathrm{~cm}$ Diatas permukaan bedengan di taburi jenis pupuk kandang sesuai dosis pada masing masing petak perlakuan.

3. Pemupukan

Pemberian pupuk organik (pupuK kandang) kotoran ayam, kotoran sapi dan limbah kotoran biogas sapi disesuaikan dengan perlakuan pada setiap petak, masing masing petak perlakuan diberi perlakuan dosis 1 $\mathrm{kg} /$ petak. Pemberian pupuk kandang (organik) ini dilakukan dengan cara disebar merata di atas permukaan tanah, kemudian diratakan dengan tanah dengan menggunakan cangkul dan garfu hingga merata dengan tanah. Pemupukan dilakukan satu minggu sebelum tanam dengan tujuan agar pupuk kandang (organik) yang digunakan telah tercampur dengan tanah. 


\section{Median Volume X Nomor 2 Bulan Juni 2018}

\section{Penanaman}

Penanaman tanaman sawi hijau dilakukan pada sore hari. Dengan jarak tanam $25 \mathrm{~cm} \times 25 \mathrm{~cm}$. kemudian diberikan naungan dengan atap yang terbuata dari jarring (paranet berwarna hitam).

5. Pemeliharaan

Pemeliharaan adalah hal yang penting sehingga akan sangat berpengaruh terhadap hasil yang akan didapat. Pertama-tama yang perlu diperhatikan adalah penyiraman, penyiraman dilakukan pada pagi dan sore hari jika tidak turun hujan. Selanjutnya tahap berikutnya adalah penyulaman, penyulaman ialah tindakan penggantian tanaman ini dengan tanaman baru jika tanaman tidak tumbuh atau mati. Penyiangan dilakukan 2 kali selama masa penanaman sawi hijau, disesuaikan dengan kondisi lingkungan tanaman pada masing-masing perlakuan. Apabila perlu dilakukan penggemburan dan pengguludan bersamaan dengan penyiangan. Pengedalian hama penyakit dilakuan jika terjadi tanda-tanda serangan hama dan penyakit.

6. Pemanenan

Pemanenan dilakukan setelah tanaman sawi hijau berumur 30 hari setelah tanam. Kriteria panen tanaman sawi hijau ketika daun paling bawah menunjukkan warna kuning dan belum berbunga.

\section{Variabel Pengamatan}

Adapun variabel yang diamati dalam kajian ini yaitu sebagai berikut :

1. Tinggi tanaman $(\mathrm{cm})$ diamati selama pertumbuahan, dengan cara diukur dari pangkal batang sampai ke ujung daun pada umur 1, 2, 3 dan 4 minggu setelah tanam.

2. Jumlah daun (Helai) diamati selama pertumbuhan dengan cara dihitung jumlah daun pada umur 1, 2, 3 dan 4 minggu setelah tanam.

3. Bobot segar tanaman (g) ditimbang pada saat panen dengan menimbang semua bagian tanaman yang meliputi akar, batang dan daun.

4. Bobot segara tanaman $(\mathrm{kg})$ per petak diperoleh dengan menimbang semua bagian tanaman yang meliputi akar, batang dan daun, dilakukan pada akhir penelitian.

\section{Analisis Data \\ Hasil penelitian ditabulasi selanjutnya dianalisis dengan menggunakan analisis sidik ragam (Anova) sesuai dengan rancangan yang digunakan apabila berpengaruh nyata, maka dilanjutkan dengan Uji Beda Nyata Terkecil (BNT) Pada taraf kepercayaan $0,05 \%$.}

\section{HASIL DAN PEMBAHASAN Hasil}

\section{Tinggi Tanaman}

Tinggi tanaman sawi hijua pada umur $1-4$ minggu setelah tanam dan sidik ragamnya disajikan pada Tabel. Lampiran 1a,1b, 2a, 2b, 3a, 3b dan 4a, 4b. Sidik ragam menunjukkan bahwa pemberian jenis pupuk kandang berpengaruh nyata terhadap tinggi tanaman sawi hijau pada umur 2,3 dan 4 minggu setelah tanam, tetapi tidak berpengaruh nyata pada umur 1 minggu setelah tanam. Rataan tinggi tanaman dapat dilihat pada tabel 1 . 


\section{Median Volume X Nomor 2 Bulan Juni 2018}

Tabel 1. Rata-rata Tinggi Tanaman Sawi hijau (cm) Umur 2, 3 dan 4 MST Pada Perlakuan Jenis Kandang

\begin{tabular}{lccc}
\hline \multirow{2}{*}{ Perlakuan Pupuk kandang } & \multicolumn{3}{c}{ Tinggi Tanaman } \\
\cline { 2 - 4 } & $2 \mathrm{MST}$ & $3 \mathrm{MST}$ & $4 \mathrm{MST}$ \\
\hline $\mathrm{K}_{0}=$ Kontro & $18.33^{\mathrm{b}}$ & $24.58^{\mathrm{b}}$ & $26.70^{\mathrm{a}}$ \\
$\mathrm{K}_{1}=$ Pupuk kandang ayam 1 kg/petak & $21.24^{\mathrm{a}}$ & $26.24^{\mathrm{a}}$ & $28.13^{\mathrm{b}}$ \\
$\mathrm{K}_{2}=$ Pupuk kandang sapi 1 kg/petak & $21.82^{\mathrm{a}}$ & $26.35^{\mathrm{a}}$ & $27.09^{\mathrm{a}}$ \\
$\mathrm{K}_{3}=$ Pupuk kandang biogas 1 kg/petak & $21.55^{\mathrm{a}}$ & $26.37^{\mathrm{a}}$ & $29.30^{\mathrm{b}}$ \\
\hline $\mathrm{NP}_{\text {BNT }}$ & 1.4074 & 0.9055 & 0.7474 \\
\hline
\end{tabular}

Keterangan : Angka-angka yang diikuti oleh huruf yang sama pada kolom yang sama berarti berbeda tidak nyata pada taraf uji BNT 0,05

Tabel 1 menunjukkan bahwa pemberian pupuk kandang sapi $\left(\mathrm{k}_{2}\right)$ memberikan pengaruh nyata terhadap tinggi tanaman pada umur 2 MST $(21.82 \mathrm{~cm})$, dan berbeda nayata dengan perlakuan lainnya. Sedangkan perlakuan pupuk kandang biogas $\left(\mathrm{k}_{3}\right)$ berpengaruh nayata terhadap tinggi tanaman pada umur 3 minggu setelah tanam, $(26.37 \mathrm{~cm})$ dan 4 minggu setelah tanam $(29.30 \mathrm{~cm})$ dan berbeda nyata dengan perlakuan $\left(\mathrm{k}_{2}\right)$ pada umur 3 miggu setelah tanam, tetapi berbeda nyata dengan perlakuan lainnya dan kontrol $\left(\mathrm{k}_{0}\right)$.

\section{Jumlah Daun}

Jumlah daun tanaman sawi hijau pada umur 1 - 4 minggu setelah Tanam dan sidik ragamnya disajikan pada Tabel Lampiran 2a, 2b, 3a, 3b, 4a, 4b dan 5a, 5b. Sidik ragam menunjukkan bahwa pemberian jenis pupuk kandang berpengaruh nyata dan sangat nyata terhadap jumlah daun tanaman sawi hijau pada umur 3 dan 4 minggu setelah tanam, tetapi tidak berpengaruh nyata pada umur 1 dan 2 minggu setelah tanam. Rataan jumlah daun tanaman dapat dilihat pada tabel 2 .

Tabel 2. Rata-rata Jumlah Daun Tanaman Sawi Hijau (helai) Umur 3 dan 4 MST Pada Perlakuan Jenis PupukKandang.

\begin{tabular}{lcc}
\hline \multirow{2}{*}{ Perlakuan Jenis pupuk kandang } & Jumlah daun & \\
\cline { 2 - 3 } & $3 \mathrm{MST}$ & $4 \mathrm{MST}$ \\
\hline $\mathrm{K}_{0}=$ Kontrol & $4.97^{\mathrm{b}}$ & $5.05^{\mathrm{a}}$ \\
$\mathrm{K}_{1}=$ Pupuk kandang ayam 1 kg/petak & $5.43^{\mathrm{a}}$ & $5.50^{\mathrm{a}}$ \\
$\mathrm{K}_{2}=$ Pupuk kandang sapi 1 kg/petak & $5.58^{\mathrm{a}}$ & $6.03^{\mathrm{a}}$ \\
$\mathrm{K}_{3}=$ Pupuk kandang biogas 1 kg/petak & $5.56^{\mathrm{a}}$ & $6.05^{\mathrm{b}}$ \\
\hline $\mathrm{NP}_{\text {BNT }}$ B $_{0,05}$ & 0.3645 & 0.6642 \\
\hline
\end{tabular}

Keterangan : Angka-angka yang diikuti huruf sama pada baris $(a, b)$ berarti berbeda tidak nyata pada taraf uji BNT 0,05

Tabel 2 menunjukkan bahwa pemberian pupuk kandang sapi $\left(\mathrm{k}_{2}\right)$ berpengaruh nyata terhadap jumlah daun tanaman sawi hijau terbanyak pada umut 3 minggu setelah tanam (5.58 helai) tetapi tidak berbedanyata dengan perlakuan $\left(\mathrm{k}_{3}\right)$ sedang perlakuan pupuk kandang biogas $\left(\mathrm{k}_{3}\right)$ berpengaruh nyata terhadap jumlah daun pada umur 4 minggu setelah tanam (6.05 helai) dan berbeda tidk nyata dengan perlakuan $\left(\mathrm{K}_{2}\right)$ tetapi berbeda nyata dengan perlakuan lainnya dan kontrol $\left(\mathrm{k}_{0}\right)$. 


\section{Median Volume X Nomor 2 Bulan Juni 2018}

\section{Bobot Segar Tanaman (g)}

Bobot segar per tanaman sawi hijau dan sidik ragamnya disajikan pada Tabel Lampiran 6a dan 6b. Sidik ragam menunjukkan bahwa pemberian berbagai jenis pupuk kandang berpengaruh nyata terhadap bobot segar per tanaman.

Tabel 3. Rata-rata bobot segar per tanaman sawi hijau (g) pada berbagai jenis pupuk kandang

\begin{tabular}{lcc}
\hline \multicolumn{1}{c}{ Perlakuan } & Rata-rata & NP BNT $_{0,05}$ \\
\hline $\mathrm{K}_{0}=$ Kontro & $197.48^{\mathrm{a}}$ & 7.8955 \\
$\mathrm{~K}_{1}=$ Pupuk kandang ayam $1 \mathrm{~kg} /$ petak & $212.46^{\mathrm{a}}$ & \\
$\mathrm{K}_{2}=$ Pupuk kandang sapi $1 \mathrm{~kg} /$ petak & $227.32^{\mathrm{b}}$ & \\
$\mathrm{K}_{3}=$ Pupuk kandang biogas $1 \mathrm{~kg} /$ petak & $219.23^{\mathrm{b}}$ & \\
\hline
\end{tabular}

Keterangan : Angka yang diikuti huruf sama pada baris $(a, b)$ berarti berbeda tidak nyata pada taraf uji BNT 0,05

Tabel 3 menunjukkan bahwa pemberian pupuk kandang sapi $\left(\mathrm{k}_{2}\right)$ memberikan bobot segar per tanaman sawi hijau terberat $(227.32 \mathrm{~kg})$ dan berbeda sangat nyata dengan perlakuan lainnya dan tanpa perlakuan $\left(\mathrm{k}_{0}\right)$

\section{Bobot Segar Tanaman per Petak (kg)}

Bobot segar tanaman sawi hijau per petak dan sidik ragamnya disajikan pada Tabel Lampiran $7 \mathrm{a}$ dan $7 \mathrm{~b}$. Sidik ragam menunjukkan bahwa pemberian jenis pupuk kandang berpengaruh sangat nyata terhadap bobot segar tanaman sawi per petak.

Tabel 4. Rata-rata bobot segar tanaman sawi hijau per petak $(\mathrm{kg})$ pada berbagai jenis pupuk kandang

\begin{tabular}{lcc}
\hline \multicolumn{1}{c}{ Jenis pupuk kandang } & Rata-rata & \multirow{2}{*}{$\mathrm{NP} \mathrm{BNT}_{0,05}$} \\
\hline $\mathrm{K}_{0}=$ Kontro & $2.04^{\mathrm{a}}$ & 0.1793 \\
$\mathrm{~K}_{1}=$ Pupuk kandang ayam 1 kg/petak & $2.60^{\mathrm{a}}$ & \\
$\mathrm{K}_{2}=$ Pupuk kandang sapi $1 \mathrm{~kg} /$ petak & $2.82^{\mathrm{b}}$ & \\
$\mathrm{K}_{3}=$ Pupuk kandang biogas $1 \mathrm{~kg} /$ petak & $2.88^{\mathrm{b}}$ & \\
\hline
\end{tabular}

Keterangan: Angka-angka yang diikuti huruf sama pada baris (a,b) berarti berbeda tidak nyata pada taraf uji BNT 0,05

Tabel 4 menunjukkan bahwa pemberian pupuk kandang biogas $\left(\mathrm{k}_{3}\right)$ memberikan bobot segar tanaman sawi hijau per petak terberat $(2.88 \mathrm{~kg})$ dan berbeda sangat nyata dengan perlakuan $\left(\mathrm{k}_{2}\right.$ dan $\left.\mathrm{k}_{1}\right)$ dan kontrol.

\section{Bobot Segar kg/ ha}

Bobot segar tanaman sawi hijau $\mathrm{kg} /$ ha dan sidik ragamnya disajikan pada Tabel Lampiran 11a dan 11b. Sidik ragam menunjukkan bahwa pemberian berbagai jenis pupuk kandang berpengaruh sangat nyata terhadap bobot segar tanaman sawi hijau kg/ ha. 


\section{Median Volume X Nomor 2 Bulan Juni 2018}

Tabel 5. Rata-rata Bobot Segar Tanaman Sawi Hijau ton/ha Pada Berbagai Jenis Pupuk Kandang

\begin{tabular}{lcc}
\hline \multicolumn{1}{c}{ Perlakuan Jenis Pupuk kandang } & Rata-rata & NP BNT $(0,05)$ \\
\hline $\mathrm{K}_{0}=$ Kontro & $2.27 \mathrm{~b}$ & 0.1793 \\
$\mathrm{~K}_{1}=$ Pupuk kandang ayam $1 \mathrm{~kg} /$ petak & $2.43^{\mathrm{b}}$ & \\
$\mathrm{K}_{2}=$ Pupuk kandang sapi $1 \mathrm{~kg} /$ petak & $2.50^{\mathrm{b}}$ & \\
$\mathrm{K}_{3}=$ Pupuk kandang biogas $1 \mathrm{~kg} /$ petak & $2.67^{\mathrm{a}}$ & \\
\hline
\end{tabular}

Keterangan : Angka-angka yang diikuti huruf sama pada baris $(a, b)$ berarti berbeda tidak nyata pada taraf uji BNT 0,05

Tabel 5 menunjukkan bahwa pemberian pupuk kandang biogas $\left(\mathrm{k}_{3}\right)$ memberikan bobot segar tanaman sawi hijau ton/ha terberat $(2,67)$ dan dan berbeda sangat nyata dengan perlakuan $\left(\mathrm{k}_{1}\right.$ dan $\mathrm{k}_{2}$ dan tanpa perlakuan $\left(\mathrm{k}_{0}\right)$

\section{Pembahasan}

Dari hasil analisis statistik menunjukan bahwa pemberian berbagai jenis pupuk kandang (organik) berpengaruh nyata dan sangat nyata terhadap tinggi tanaman, jumlah daun, bobot segar tanaman, dan bobot segar tanaman per petak. Pengaruh dari ketiga perlakuan pupuk kandang kotoran ayam, sapi dan pupuk biogas, jelas akan memperkaya kandungan unsur hara pada tanah. Baik pada kotoran sapi, ayam maupun pupuk kandang biogas. Ketiga jenis pupuk kandan (bahan organik) ini mempunyai kandungan unsur hara lengkap dengan proporsi yang berbeda dan saling melengkapi satu sama lain. Selain mengandung unsur-unsur makro (Nitrogen, Fosfor, Kalium) juga mengandung unsur-unsur mikro (Kalsium, Magnesium, serta sejumlah kecil mangan, tembaga, borium dll) yang dapat menyediakan unsur-unsur atau zat makanan bagi kepentingan pertumbuhan dan perkembangan tanaman. Selain itu, pupuk organik dari ketiga jenis kandang (kotoran ternak) ini memiliki kelebihan yaitu memperbaiki sifat fisik, kimia, serta biologi tanah, menaikkan daya serap tanah terhadap air, menaikkan kondisi kehidupan di dalam tanah serta sebagai sumber zat makanan bagi tanaman (Sutedjo, 2008). Pengaruh perlakuan dari masing masing pupuk kandang terhadap setiap variabel pengamatan dapat dijelas sebagai berikut.

Hasil pengamatan terhadap tinggi tanaman sawi menunjukan bahwa pemberian pupuk kandang berpengaruh nyata terhadap tinggi tanaman sawi pada umur 2, 3 dan 4 minggu setelah tanaman, tetapi tidak berpengaruh pada umur 1 minggu setelah tanam. Hasil uji BNT 5\% menunjukkan bahwa pengaruh pupuk kadang terhadap jumlah daun tanaman sawihijau tertinggi pada umur 2 minggu setelah tanam yaitu $(21,82$ $\mathrm{cm})$ dan 4 minggu setelah tanam yaitu $(29,30 \mathrm{~cm})$ diperoleh pada perlakuan pupuk organik kandang sapi $\left(\mathrm{k}_{2}\right) 1$ $\mathrm{kg} /$ petak dan terendah terdapat pada perlakuan tanpa pupuk $\left(\mathrm{k}_{0}\right)$ yaitu 2 minggu setelah tanam $(21,82 \mathrm{~cm})$ dan 4 minggu setelah tanam yaitu $(29,30 \mathrm{~cm})$ Sedangkan tinggi tanaman tertinggi pada umur 3 minggu setelah tanam, diperoleh pada perlakuan pupuk organik kandang biogas $\left(\mathrm{k}_{3}\right) 1 \mathrm{~kg} /$ petak, yaitu $(26.37 \mathrm{~cm})$ dan terendah diperoleh pada perlakuan tanpa pupuk $\left(\mathrm{k}_{0}\right)$ yaitu $(24,58$ $\mathrm{cm})$.

Hasil pengamatan terhadap jumlah daun tanaman sawi menunjukan bahwa pemberian pupuk kandang berpengaruh nyata terhadap jumlah daun tanaman sawi pada umur 3 dan 4 minggu setelah tanaman, tetapi tidak 


\section{Median Volume X Nomor 2 Bulan Juni 2018}

berpengaruh pada umur 1 dan 2 minggu setelah tanam. Hasil uji BNT 5\% menunjukkan bahwa pengaruh pupuk kadang terhadap jumlah daun tanaman sawi terbanyak pada umur 2 MST diperoleh pada perlakuan pupuk organik kandang sapi $\left(\mathrm{k}_{2}\right) 1 \mathrm{~kg} /$ petak yaitu (5,58 helai) dan terendah terdapat pada perlakuan tanpa pupuk $\left(\mathrm{k}_{0}\right)$ yaitu $(4,97$ helai). Sedangkan jumlah daun tertinggi pada umur 4 MST diperoleh pada perlakuan pupuk organik kandang biogas $\left(\mathrm{k}_{3}\right) 1 \mathrm{~kg} / \mathrm{petak}$, yaitu $(6.05$ helai) dan terendah diperoleh pada perlakuan tanpa pupuk $\left(\mathrm{k}_{0}\right)$ yaitu $(5,05$ helai).

Sedangkan pada umur 3-4 minggu setelah tanam memperlihatkan adanya pengaruh dari perlakuan pupuk kandang yang diberikan. Hal ini diduga karena pemberian pupuk kandang terutama kotoran sapi dan limbah sampingan hasil biogas yang berfungsi sebagai pupuk organik untuk menyuburkan tanah disesuaikan dengan kualitas dan kuantitas bahan organik yang terurai didalam tanah. Pemberian pupuk kandang sapi dan biogas dapat menyediakan unsur hara lebih baik dibandingkan perlakuan lainnya. Unsur Nitrogen yang tersedia dalam kedua bahan tersebut dalam jumlah yang cukup dapat meningkatkan jumlah daun dan laju fotosintesis tanaman, sehingga daun dapat menghasilkan fotosintat dan energi yang lebih tinggi untuk pertumbuhan dan produksinya $\mathrm{Hal}$ ini sesuai pendapat Novizan (2005), bahwa pemupukan yang efektif melibatkan persyaratan kuantitatif dan kualitatif. Persyaratan kuantitatif adalah dosis pupuk, jumlah pupuk, waktu pemupukan dan cara pemupukan. Sedangkan persyaratan kualitatif meliputi unsur hara yang diberikan melalui pemupukan yang relevan dengan nutrisi yang ada, waktu pemupukan dan penempatan pupuk secara tepat sehingga unsur hara tersebut dapat diserap oleh tanaman.

Hasil pengamatan terhadap bobot segar tanaman sawi menunjukan bahwa pemberian pupuk kandang berpengaruh nyata terhadap bobot segar tanaman sawi Hasil uji BNT 05\% menunjukkan bahwa pengaruh pupuk kadang terhadap jumlah bobot segar tanaman tanaman sawi hijau terberat diperoleh pada perlakuan pupuk organik kandang sapi $\left(\mathrm{k}_{2}\right) 1 \mathrm{~kg} /$ petak yaitu $(227.32 \mathrm{gr})$ dan terendah terdapat pada perlakuan tanpa pupuk $\left(\mathrm{k}_{0}\right)$ yaitu (197.48 gr). Hal ini disebakan karena pupuk kandang kotoran sapi yang diberikan mengandung unsur hara Nitrogen $(\mathrm{N})$ yang berperan terhadap pertumbuhan vegetatif tanaman juga mengandung hara Phosfor (P) dan Kalium (K). Kedua unsur ini tentunya punya peran yang sangat penting juga dalam proses metabolisme tanaman sehingga mendukung pertumbuhan dan produksi tanaman dalam hal ini bobot tanama sawi hijau.

Hasil pengamatan terhadap bobot segar tanaman sawi menunjukan bahwa pemberian pupuk kandang berpengaruh nyata terhadap bobot segar tanaman sawi kg petak. Hasil uji BNT 05\% menunjukkan bahwa pengaruh pupuk kandang terhadap jumlah bobot segar tanaman tanaman sawi per petak terberat diperoleh pada perlakuan pupuk kandang biogas $\left(\mathrm{k}_{3}\right) 1 \mathrm{~kg} /$ petak yaitu $(2,88 \mathrm{~kg})$ dan terendah terdapat pada perlakuan tanpa pupuk $\left(\mathrm{k}_{0}\right)$ yaitu $(2,04$ $\mathrm{kg}$ ). Hal ini disebabkan karena bahan organik dari sisa proses pembuatan biogas dapat dijadikan pupuk walaupun bentuknya berupa lumpur. Namun lumpur dari biogas yang telah hilang gasnya merupakan pupuk organik yang kaya akan unsur-unsur yang dibutuhkan oleh tanaman seperti N, P dan K. Kandungan N, P dan K dari lumpur yang dihasilkan dari biogas 
lebih meningkat jika dibandingkan dari kotoran yang langsung digunakan sebagai pupuk dikarenakan lumpur telah mengalami proses fermentasi.

Jumlah unsur-unsur tersebut cukup untuk memenuhi kebutuhan hara tanaman sehingga memberikan hasil yang lebih baik. Kenyataan ini sesuai dengan pendapat Lingga (2000) yang mengatakan bahwa berat total hasil pertanian juga memerlukan unsur hara terutama Nitrogen, Fosfor dan Kalium. Nitrogen diperlukan untuk pembentukan klorofil yang berguna bagi proses fotosintesis, dan pembentukan protein dan lemak. Unsur fosfor juga berguna untuk merangsang pertumbuhan akar, pembentukan sistim perakaran yang baik dari tanaman muda untuk mempercepat pertumbuhan pegetatif dan hasil tanaman.

Hasil pengamatan terhadap bobot segar tanaman sawi hijau ton/ha menunjukan bahwa pemberian pupuk kandang berpengaruh nyata terhadap bobot segar tanaman sawi hijau ton/ha. Hasil uji BNT 5\% menunjukkan bahwa pengaruh pupuk kadang biogas terhadap bobot segar tanaman tanaman sawi hijau ton/ha terberat diperoleh pada perlakuan pupuk organik kandang biogas $\left(\mathrm{k}_{3}\right) 1 \mathrm{~kg} /$ petak yaitu (2,67 ton) dan terendah terdapat pada perlakuan tanpa pupuk $\left(\mathrm{k}_{0}\right)$ yaitu (2,27 ton/ha). Hal ini disebabkan karena tingginya produksi bobot segar tanaman sawi hijau akibat perlakuan pupuk kandang biogas tidak lepas dari pengaruh hasil bersih fotosintesis. Peningkatan hasil tanaman sawi hijau didukung oleh pertumbuhan vegetatif seperti jumlah daun, jumlah cabang dan berangkasan tanaman menjadi indikator pertumbuhan generatif hasil tanaman. Menurut Hardjowigeno (1992), dalam Styaningrum, dkk (2013) mengatakan bahwa aplikasi pupuk kandang biogas dapat memperbaiki aerase tanah, menambah menamabah unsur hara, meningkatkan kapasitas menahan air, dan daya sangga tanah, sumber energi bagi mikroorganisme tanah dan sebagai sumber unsur hara.

\section{KESIMPULAN}

Berdasarkan hasil yang diperoleh, maka dapat disimpulkan sebagai berikut:

1. Pemberian berbagai jenis Organik kandang sapi $\left(\mathrm{k}_{2}\right) 1 \mathrm{~kg}$ perpetak $(227,32$ gr) dan berbeda dengan tanpa perlakuan pupuk $\left(\mathrm{k}_{0}\right)$ mencapai $(197,48$ gr) sangat nyata terhadap semua komponen yang diamati pada tanaman sawi hiju.

2. Jenis bokashi pupuk kandang ayam memberikan pengaruh terbaik pada tinggi tanaman, jumlah daun, bobot segar per tanaman, pada 2 minggu setelah tanam $(21,82 \mathrm{~cm})$, dan per Ha tanaman sawi hijau.

\section{DAFTAR PUSTAKA}

Andayani dan Sarido, L. 2013. Uji Empat Jenis Pupuk Kandang Terhadap Pertumbuhan dan Hasil Tanaman Cabai Keriting (Capsicum annum L.) Jurnal AGRIFOR Volume XII Nomor 1, Maret 2013. ISSN : $1412-6885$.

Cahyono, B. 2003. Teknik dan Strategi Budidaya Sawi Hijau (Pai-Tsai). Yayasan Pustaka Nusatama. Yogyakarta

Edi, Syafrif dan Julistia Bobihoe. 2010.

Budidaya Tanaman Sayuran.

Jambi : Balai Pengkajian

Teknologi Pertanian (BPTP) Jambi.

Gomez. K.A and Gomez. A.A. Statistical Procedures For Agricultural Research. JohnWileydanSons,Inc.1995.

Habibi, 2009. Pembuatan Pupuk Kompos Dari Limbah Rumah 


\section{Median Volume X Nomor 2 Bulan Juni 2018}

Tangga. Buku dalam Penulisan Pengertian Kompos dan Manfaat Kompos. Penerbit Titian Ilmu : Bandung.

Hakim, N., Yusuf Nyakpa, A.M. Lubis, Sutopo Ghani, Rusdi saul, M. Amin Diha, Go Ban Hong, $\mathrm{H}$. Bailey. 2006. Dasar-dasar Ilmu Tanah. Universitas Lampung, Lampung.

Harjadi, 2006. Pengantar Agronnomi. PT. Gramedia, Jakarta

Haryanto E, Suhartini T, Rahayu E, dan Sunarjono H. 2005. Sawi dan Selada. Depok: Penebar Swadaya. Hanafiah K.A, 2003 Rancangan Percobaan Teori dan Aplikasi, Fakultas Pertanian Universitas Sriwijaya, Palembang. PT.Raja Grafindo Persada Jakarta Utara.

Jumin, H., B. 2006. Dasar-Dasar Agronomi. Rajawali Press. Jakarta.

Lingga, P, 2000. Petunjuk Penggunan Pupuk, Seri Agritekno. Penebar Swadaya. Jakarta.

Lingga, P dan Marsono, 2006. Petunjuk Penggunaan Pupuk. Penebar Swadaya. Jakarta.

Marpua, E. Monica, Amali, V. Nussifa, N, 2014. Tugas Makalah Digester Biogas. Universitas Diponegoro Jurusan Peternakan Fakultas Pertanian dan Peternakan. http://www.academia.edu/8387886.biog as. Di akses tanggal 11 November 2017.

Munawar, A. 2011. Kesuburan Tanah dan Nutrisi Tanaman. Bogor : IPB Press

Nasaruddin, 2008. Budidaya dan Pengaturan Panen Sayuran Dataran Rendah. Penebar Swadaya, Jakarta. Palangkung D dan A. Budiarti, 1996. Sayur Komersial. Penebar Swadaya, Jakarta.
Nurshanti, D.F. 2009. Pengaruh Pemberian Pupuk Organik Terhadap Pertumbuhan dan Hasil Tanaman Sawi Caisim (Brassica Juncea L.). Vol. 1,pp.89-98.

Nurhasanah. 2005. Biogas Sebagai Energi Alternatif. Penerbit Media Pustaka Press. Jakarta.

Novizan, 2005. Petunjuk Pemupukan Yang Efektif, Kiat Mengatsi Permasalahan Praktis. Agromedia fustaka . jakarta

Rahmawati, 2008. Pengaruh Dua Macam Pupuk Kandang dan Urea Terhadap Pertumbuhan dan Produksi Polong Muda Kacang Tunggak (Vigna unguiculata L.). Jurusan Budidaya Pertanian Fakultas Pertanian dan Kehutanan Universitas Hasanuddin, Makassar.

Renawati. 2012. Pengunaan pupuk pandang dengan kondisi yang berbeda terhadap pertumbuhan dan hasil tanaman sawi (Brassica Juncea L.). Skripsi. Program Studi Agronomi. Fakultas Pertanian dan Peternakan. Universitas Islam Negeri Sultan Syarif Kasim Riau.

Rinsema, 2003. Pupuk dan Pemupukan. CV. Spimpleks, Jakarta.

Rukmana, R. 2004. Bertanam Petsai dan Sawi. Yogyakarta: Kanisius.

Jumin, H., B. 2006. Dasar-Dasar Agronomi. Rajawali Press. Jakarta.

Samekto, R. 2006. Pupuk Kandang. Penerbit PT Citra Aji Parama. Jakarta.

Sanusi, A , Setyono2, Sjarif A. Adimihardja, 2015. Pertumbuhan Dan Produksi Sawi Manis (Brassica juncea L.) Pada Berbagai Dosis Pupuk Kompos Ternak Sapi Dan Pupuk N, P Dan K. Jurnal Agronida ISSN 2407- 


\section{Median Volume X Nomor 2 Bulan Juni 2018}

9111 Volume 1 Nomor 1, April 2015.

Santoso, R. 2014. Cara Membuat Biogas Dari Kotoran Sapi. http://bertani-di.blogspot.sg /2014/07/cara-membuat-biogasdari-kotoran-sapi.html. Di akses tanggal 27 Oktober, 2017

Sarief, S., 2002. Kesuburan dan Pemupukan Tanah Pertanian. Pustaka Buana, Bandung.

Setyamidjaja, 2006. Pupuk dan Pemupukan. CV Simplekx, Jakarta.

Setiawan, A. I. 2008. Memanfatkan Kotoran Ternak. Penebar Swadaya. Jakarta.

Setiawan. A. I, 2005. Sayuran Dataran Tinggi, Penebar Swadaya, Jakarta. Styaningrum, L. Koesriharti dan Magfur D. 2013. Respons Tanaman Buncis (Phaseolus vulgaris L.) Terhadap Dosis Pupuk Kandang Kambing dan Pupuk Daun yang Berbeda. Jurnal Produksi Tanaman Volume 1 No.1. Maret 2013

Suyanto, A. 2004. Seri PHT Hama Sayur dan Buah. PT. Penebar Swadaya, Jakarta.

Sulistiowati, R. dan Susanti, S. 2017. Pengaruh Macam Dan Dosis Pupuk Kandang Terhadap Pertumbuhan Dan Hasil Tanaman Petsai (Brassica chinensis L.). https://www.upm.ac.id/. Akses tgl 15 November, 2017.

Suleman, D. Cindra, Nelson, $\mathrm{P}$ dan Nurmi, 2013. Pertumbuhan dan
Produksi Tanaman Sawi (brassica juncea 1.) Dengan Pemberian Dosis Pupuk Organik Kotoran Ayam.

Sutedjo. M. M. 2008. Pupuk Dan Cara Pemupukan. Rineka Cipta. Jakarta. Cetakan Kedelapan

Winarto, F. 2010. Penamabahan Tepung Darah Dalam Pembuatan Pupuk Organik Padat Limbah biogas dari Feses Sapi dan Sampah Organik Terhadap Kandungan N, P dan K. Skripsi Fakultas Peternakan Universitas Andalas Padang. http://repository.unand.ac.id. Di akses tanggal 20 November, 2017.

Wikipedia, 2014. Kotoran sapi. http://id.wikipedia.org/wiki/Kotor an_sapi. Di akses tanggal, 25 November, 20017.

Yuliana, Elf, Rdani dan Indah permanasari, 2017. Aplikasi Pupuk Kandang Sapi dan Ayam Terhadap Pertumbuhan dan Hasil Tanaman Jahe (Zingiber officinale rosc.) Di Media Gambut, Jurnal Agroteknologi. Vol 5 No. 2, Februari 2015 : 37-42 37

Zulkarnain, M., Prasetya, B., dan Soemarno. 2013. Pengaruh kompos, pupuk kandang, dan custom-bio terhadap sifat tanah, pertumbuhan dan hasil tebu (Saccharum officinarum L.) pada entisol di kebun Ngrakah-Pawon Kediri. Indonesian 